Apuntes Universitarios, 2021: 11(1), enero-marzo

ISSN: 2304-0335 DOI: https://doi.org/10.17162/au.v11i1.574

\title{
Explicando los efectos económicos y ambientales de la calidad de vida sobre la retención de la población en residencias rurales
}

\section{Explaining the economic and environmental effects of quality of life on the retention of population in rural residences}

\author{
Nahid Goli ${ }^{1}$, Dr. Mehdi Jahani ${ }^{2 a}$, Dr. Abolfazl Behnia-Far ${ }^{3}$ \\ Islamic Azad University, Mashhad, Iran ${ }^{123}$ \\ Dorcid ID: https://orcid.org/0000-0001-9388-3110 1 \\ D Orcid ID: https://orcid.org/0000-0002-2700-0196 2 \\ (iD) Orcid ID: https://orcid.org/0000-0002-5930-15403
}

Recibido: 28 de mayo de 2020

Aceptado: 27 de octubre de 2020

\begin{abstract}
Resumen
El objetivo de este estudio fue explicar los efectos económicos y ambientales de la calidad de vida en la retención de población en residencias rurales. Comprende una investigación aplicada, y en términos de naturaleza y métodos, se considera descriptivo-analítico. Con el fin de recopilar datos, se han realizado estudios de campo y estudios de biblioteca. Para ello, se preparó un cuestionario índice basado en la Escala Likert y se distribuyó aleatoriamente entre los pobladores. La población del estudio incluye 2570 individuos; sin embargo, utilizando la fórmula de Cochran, el tamaño de la muestra del estudio se determinó como 356 individuos. Los cuestionarios recogidos se han analizado mediante estadística descriptiva, prueba $\mathrm{T}$ y regresión multivariante. Los resultados muestran que las ecuaciones estructurales, con un valor superior a 0.05 y un estadístico t de 1.072, se registra el efecto del aspecto financiero de la calidad de vida sobre la retención de la población. Además, los resultados también han manifestado que el aspecto ambiental de la calidad de vida también es efectivo en el primero con un valor de 0,05 y un estadístico t de 2,017, que es superior al valor crítico de 1,96. Se puede concluir que el aspecto ambiental de la calidad de vida es significativamente efectivo en la retención de la población en las residencias rurales; sin embargo, considerando el coeficiente de trayectoria obtenido de 0,208 , se concluye que el aspecto económico de la calidad de vida no tiene efectos significativos conocidos sobre la retención de la población en las zonas rurales.
\end{abstract}

Palabras clave: Economía, ciencia ambiental, calidad de vida, vida rural, Irán

a Corresponding Author: E-mail: j.jahani@yahoo.com 


\begin{abstract}
The objective of this study was to explaining the economic and environmental effects of quality of life on the retention of population in rural residences. This shows an applied research, and in terms of nature and methods, it is considered as a descriptive-analytical one. For the purpose of data collection, field studies and library studies have been conducted. To this end, an index questionnaire based on the Likert Scale was prepared and randomly distributed among the villagers. The population of the study includes 2570 individuals; however, using the Cochran's formula, the sample size of the study was determined as 356 individuals. The collected questionnaires have been analyzed through descriptive statistics, T-test and, multivariate regression. Results show that structural equations, with a value of over 0.05 and t-statistic of 1.072, the effect of the financial aspect of life quality on retention of population is recorded. In addition, the results have also manifested that the environmental aspect of quality of life is also effective on the former with a value of 0.05 and t-statistic of 2.017, which is higher than the critical value of 1.96. Finally, it can be concluded that the environmental aspect of life-quality is significantly effective on retention of population in rural residences; however, considering the obtained path coefficient of 0.208 , it is concluded that the economic aspect of life quality is not of any known significant effects on retention of population in rural areas.
\end{abstract}

Keywords: Economics, environmental studies, quality of life, rural life, Iran

\title{
Introduction
}

The quality of life of residents is a concept that has been widely used in lectures and development programs over the centuries. It is used to provide a better life for people by upgrading it Which is a multi-level and fluid concept that expresses the happiness and well-being of people (Horváth \& Jónás-Berki, 2018). For the other hand, retention of rural population in villages is consistently related to the issue of Rural-Urban migration. On this basis it is expected that a majority of reasons causing such migrations are followed by migration of villagers from rural areas. One reason for this phenomenon is the economic problems present in the atmosphere of villages (Mathew \& Sreejesh, 2017).

Issues such as explicit and implicit unemployment, instability and insufficiency of income, rural poverty and others, which usually emerge in structures in which occupational agriculture and especially farming activities, have a high share of employment and income in absence of other sources (Su \& Swanson, 2017). In order to mitigate the negative effects of such issues and to improve the life-level of villagers which in turn results in less rural-urban migration , several different strategies have been proposed (Alavi Zadeh, 2013).

In general, if the income of rural households is insufficient, the motivation for migrating to cities and taking part in other economic activities will be so robust that it will cause in lack of 
retention of households in the villages, especially under the current circumstance of day-to-day increase in the differences between urban and rural communities (Mir Latifi, 2013). Rural-Urban migration is a phenomenon that emerged throughout the industrialization process of countries which is the main cause of many of the atmospheric and social changes in communities (Zhang Et al, 2016).

In the country of Iran, as cities began to industrialize, the process of employment of unemployed youngsters in the agriculture sector commenced in the favor of industrial and serviceprovision-related activities (Rostamalizadeh, 2013). The process of extensive migration and exiting of young and active population from villages endangers the sustainability of rural communities. One way to mitigate rural-urban migrations is to improve the sustainability of life quality in rural areas, which covers equality, sustaining cultural variability, improving the quality of life and generally, any kind of change in economic activities that would result in improvement of life quality (Noorbakhsh, 2012). Currently, the level of life quality in rural areas being low, and resultantly migration of rural people to large cities has caused several social, economic, and environmental issues in both cities and villages (Mohammadi, 2014).

\section{Definition of life quality}

Life quality is defined as the general welfare of an individual. The World Health Organization (WHO) defines life quality as people’s individual perception of their condition in life in terms of culture, goals, expectations, standards, concerns and the value-system in which they live (WHO QOL, 2010). In the view of Foo, life quality is defined as an indicator of individuals' general satisfaction with their lives (Foo, 2017). Based on all observations, quality of life is viewed as an extensive concept covering physical health, mental condition, freedom and, the relations between an individual and environmental characteristic (Clarke \& Marshall, 2000). Quality of life focuses on the entire aspects of life (Cultural, Social, Environmental, Physical, hygienic, and the system of local value). Quality is defined as modality and so the abbreviation “QoL” (Quality of Life) lexically points to the manner of life including the differences, however it's unique and distinct per person (Barany, 2014). In addition, in terms of terminology, the Persian Dictionary of Amid defines it also as manner, modality and, state (Amid Dictionary). Quality of life is universally a constituent of individual activities that project a desirable reflection for any aspect of life. The present study focuses on individuals' emotional reactions to life events, sense 
of life, needs and satisfaction, manners, and, satisfaction with occupational and personal relationships (Diener, 1997).

Furthermore, in literature also the expression of "quality of life” denotes "welfare”, a significant factor in uptake of development (Clarkel, 2015). Leo (1983) defines quality of life as a bold naming for the same old concept of economic and mental well-being in the living place. Smith defines quality of life as social well-being, while Andrews defines it as public welfare and Muller (1983) defines it as individuals' and categories’ welfare under general socioeconomic conditions. Yet another scholar views quality of life as the conditions of the environment in which people live; including pollution, quality of housing, as well as some personal traits and conditions among the public such as health and education (Pecione, 2017). Quality of life is a multidimensional subjective notion (Nilson, 2016), and it can be considered as individuals' perception of their position in life in terms of culture and value of their residence, considering the former's expectations and standards (Andrews, 1974). As a construct, quality of life has recently been the subject of several studies in various fields such as medicine, sociology, philosophy, and psychology; however, there is no sign of any extensively accepted single standard definition for quality of life (Pal \& Kumar, 2018). This is because many researchers believe that quality of life is a multidimensional relative notion affected by time, place and, personal and social value (Rezvani, 2019).

\section{Theoretical Basics}

Quality of life is not a newly introduced notion, rather it even existed in the Greek Philosophy and Aristotle has pointed to it in his discussion regarding physical happiness (Poorzaheri, 2012). Nevertheless, even different fields of science have agreed upon different definitions of the formerly mentioned notion, however, in general quality of life can be considered as a criterion for understanding the citizens' conditions and their levels of satisfaction by the truecoming of those needs that are related to the dimensions of life (Anabestaani, 2013). Having a desirable quality of life has always been and is a wish for the mankind (Qanbari, 2014).

The history of development of the concept of quality of life dates back to the era in which Aristotle lived around 385 B.C. As early as the time was, Aristotle defined happiness as having a good life or well completion of tasks. In addition, while discussing physical or the bodily happiness, he has pointed to quality of life as well. Aristotle has also been quoted to define 
happiness as some sort of dignified activity for the soul. Aristotle, has also expressed that happiness is the product of individuals dignified and valuable activities and guides the mankind towards a good life. Serious discussions focusing quality of life began only in the 1930s, but luckily since that time researchers from various science fields have studied the concept of quality of life; resulting in various versions of definitions each fitting a certain geographic area (Barimani, 2014, 586). In 1955, when an international association was founded to study the concept of quality of life, studying the notion in various fields of science began to institutionalize, and so figures such as Jean Paul Sartre and others began to pay attention to it while discussing the individual's inner states (Poortaheri, 2012, 14). In 1960s, this concept began to gain interests from the field of social sciences as well (Rezvani, 2019, 36). It was only through the former decade that it turned out that economic growth and development are not the only factors required for improving the quality of life of a nation (Dos, 2008, 233).

As the economic approach of life quality began to emerge in the 1960s and 1970s, quality of life began to be evaluated as welfare only. However, opposing to such views, Koant states that there are certain subjective dimensions that are effective in quality of life. During the late decades of the $20^{\text {th }}$ Century, with the expansion of urbanism, especially in less-developed countries, several regional atmospheric, social and economic inequalities have emerged along with multiple challenges that have occurred in human residences, especially the rural areas, under the shadow of development plans and policies. These inequalities have been followed by various social and economic issues such as rural-urban migration (Andrews \& Withey, 1976).

On this basis, many scholars and scientists have tried to focus their attention on the concept of rural life quality (Barimani, 2014). It seems that with respect to the multitude of scientific fields involved with the subject of life quality, it would be extremely difficult, challenging and or even maybe inappropriate to categorize this concept under a single field of science (Hosseini, 2015). The main problem is that there is no specific universally agreed upon and accepted definition for quality of life (Cramer, Seven \& Einar, 2004). In fact, quality of life can be defined differently under the effects of the individual's mental and physical health, freedom, and social relations with the environment, plus other factors including personal satisfaction, dimensions of life and etc. (Ruževičius, 2012).

\section{Geography of the Study}


The region under study was the sector of Razavie, located in the province of Khorasan Razavi, found in the south-east line of the Kashf Rood Valley. This region is geographically surrounded by specific and yet special natural elements that set clear boundaries for the area. In this regard, the region is on the northern and eastern directions limited by the mountains of Kape Daq and Hezar Masjed, and on the western direction leads to Kaal Taraq, and on the southwestern direction is limited by the sawed-off mountains of Khaje Morad. In addition, in terms of relative position, this region is on the northern and northwestern sides surrounded by the central region, while leading from the east to the Marzdaran areas and from the northeast to kalat, from west to Ahmad Abad sector and, from the south to the city of Fariman. The sector was established in 1992 and includes three villages (Miami, Abravan and Pain Velayat) and one town (Razavie). In the census conducted by the government of the Islamic republic of Iran back in 2012, the region's population was stated to be 50169 individuals (13566 Households), and in the census conducted in 2017, the numbers increased to 59232 individuals (16796 Households).

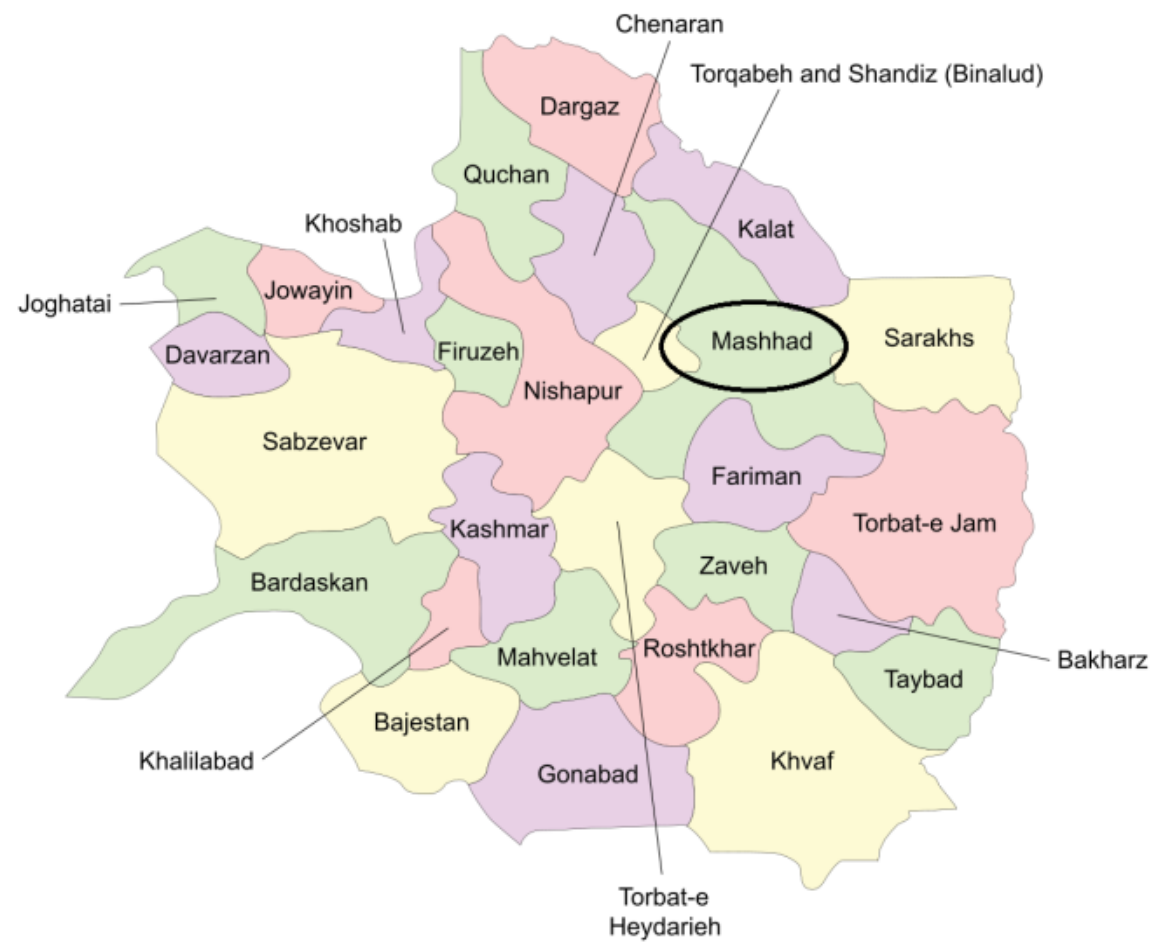

Fig 1: The region under study

Reference: Iran's Statistics Center (2017) 


\section{Research method}

In terms of objective, the present study is considered as an applied-developmental research, while in terms of nature, applied methods, and data collection manners, it is considered as a descriptive-analytical survey study. To collect the required data, firstly the various intellectual basics related to the subject matter were extracted from previously published domestic and foreign studies and were subsequently categorized. Afterwards, the research variables were extracted from a questionnaire form corresponding to the objectives of the study that was randomly distributed among the villagers. The demographic features of the population of the study have been investigated using the SPSS V.25 and the Excel 2016 software. The raw data yielding from 356 collected questionnaires were analyzed through the Structural Equations Technic using the Smart PLS v.3.0 software; after all, the raw data have been proposed as information once processed. The population of the study includes any village with over 100 households in the region of Razavie. While selecting the sample villages, first of all the villages were grouped based on the population information of the 2012 and 2017 censuses. Ultimately, considering the populations 20\% of the villages (12 villages) were selected as the sample. Since evaluating the retention of population in villages, identifying the factors effective on sustainability of the villages and also proposing the required solutions for maintaining the sustainability of rural areas are of high value, necessity and importance, the present study has tried to check the validity of the following hypotheses:

1- The economic dimension of life quality is positively effective on the retention of population in rural residences.

2- The environmental dimension of life quality is positively effective on the retention of population in rural residences. 
Table 1

The population of the study

\begin{tabular}{|c|c|c|c|c|c|}
\hline County & Village & $\begin{array}{l}\text { Female } \\
\text { Population }\end{array}$ & $\begin{array}{l}\text { Male } \\
\text { Population }\end{array}$ & $\begin{array}{l}\text { Total } \\
\text { Population }\end{array}$ & Households \\
\hline Miami & Kal Choqoki & 504 & 474 & 978 & 276 \\
\hline Miami & Chenarak & 829 & 866 & 1695 & 449 \\
\hline Miami & Mirinkash & 168 & 211 & 379 & 117 \\
\hline Pain Velayat & $\begin{array}{l}\text { Kalateh } \\
\text { Menar }\end{array}$ & 141 & 135 & 276 & 82 \\
\hline Pain Velayat & Qarne Sofla & 145 & 169 & 314 & 83 \\
\hline Pain Velayat & Derakht Bid & 93 & 100 & 193 & 55 \\
\hline Pain Velayat & $\begin{array}{l}\text { Shurak } \\
\text { Maleki }\end{array}$ & 567 & 584 & 1151 & 310 \\
\hline Pain Velayat & $\begin{array}{l}\text { Kalate } \\
\text { Mirzajani }\end{array}$ & 357 & 358 & 715 & 188 \\
\hline Abravan & $\begin{array}{l}\text { Narimani } \\
\text { Sofla }\end{array}$ & 814 & 958 & 1772 & 502 \\
\hline Abravan & Abravan & 536 & 531 & 1067 & 316 \\
\hline Abravan & Dom Roobah & 179 & 177 & 356 & 93 \\
\hline Abravan & Giami & 161 & 159 & 320 & 99 \\
\hline Total & & 4494 & 4722 & 9216 & 2570 \\
\hline
\end{tabular}

Findings

Considering the results of descriptive inspection of the views of the respondents regarding each question on the questionnaire, the abundance, validity percentage and the average values regarding each question have been reported. The items have been valued as 5: very high, 4: high, 3: average, 2: low, and 1: very low. Average values above 3 (the middle point of 5-degree Likert Scale) shows higher agreement, denoting selection of high and very high choices by the respondents. If the significance value of this test is lower than 0.05 , it is concluded that the choices have not been selected equally; however, if they obtained significance value is higher than 0.05, it is concluded that the respondents have selected similar choices.

\section{Descriptive investigation of items relating to the economic dimension}

The economic dimension of life quality is comprised of three components namely as employment, income, and investment. The following table presents the descriptive statistics of 
these items. The significance value calculated by the Chi-Do test was smaller than 0.001 for the entire questions; therefore, not all the questions have been reported in the table.

\section{Table 2}

Descriptive statistics of the items relating to the economic dimension

\begin{tabular}{cccccccc} 
Component & Index & $\begin{array}{c}\text { Very } \\
\text { Low }\end{array}$ & Low & Average & High & $\begin{array}{c}\text { Very } \\
\text { High }\end{array}$ & Median \\
\hline Employment & Abundance & 22 & 57 & 131 & 138 & 8 & 3 \\
Income & Abundance & 34 & 109 & 182 & 27 & 4 & 3 \\
Investment & Abundance & 25 & 101 & 195 & 32 & 2 & 3
\end{tabular}

While investigating the question of "state of employment in the sector of services" it has been observed that in most cases the choice of "high" is selected by the respondents (38.8\%). Furthermore, regarding the question of "state of access to proper jobs in adjacent villages" it has been observed that most respondents (39\%) have chosen the "Average" choice. While investigating the item of "income from the agriculture" it has been observed that most respondents have selected the “Average” choice (51.1\%). Nevertheless, while investigating the item of "income from the industry" it has been observed that most respondents have selected the "Average” (45.5\%) choice. Also, regarding the item of "income from the services sector" it can be seen that most respondents have selected the “Average” (42.7\%) choice.

Investigating the statistics relating to the item of “income from livestock" revealed that most respondents (54.9\%) have selected the choice “Average”. Investigating the item of "investment in agriculture" reveals that most respondents have selected the choice "Average" (44.4\%). Investigating the item of "investment in livestock" showed that most of the respondents have selected the choice "Average" (48.9\%). Elaborating on the statistics relating to the item of "investment in real estate" showed that most of the respondents have selected the choice "Average" (40.7\%). While investigating the question of "investment in industry" it was revealed that in most cases the respondents have selected the choice "Average” (41.4\%). Ultimately, also investigating the statistics of the question of "investment in the sector of services" showed that most of the respondents have selected the choice "Low" (45.5\%). 


\section{Descriptive Investigation of Items Relating to the Environmental Dimension}

The environmental dimension is comprised of two components namely as quality of the environment and, outlook and climate. The following table presents the descriptive statistics relating to these items. In addition, the significance value calculated by the Chi-do test was smaller than 0.001 for the entire question and so not all of the questions have been reported in the table.

Table 3

Descriptive investigation of items relating to the environmental dimension

\begin{tabular}{llrrrrrr} 
Component & Index & $\begin{array}{c}\text { Very } \\
\text { Low }\end{array}$ & Low & Average & High & $\begin{array}{c}\text { Very } \\
\text { High }\end{array}$ & Median \\
\hline $\begin{array}{l}\text { Quality of } \\
\text { Environment }\end{array}$ & Abundance & 46 & 81 & 114 & 91 & 21 & 3 \\
$\begin{array}{l}\text { Outlook and } \\
\text { Climate }\end{array}$ & Abundance & 89 & 122 & 79 & 34 & 30 & 2
\end{tabular}

While investigating the item of "quality of sidewalks and cleaning of the village", it was turned out that most respondents (32.3\%) had selected the choice "Average”. Elaborating on the statistics relating to the "collection and disposal of surface waters" showed that most of the respondents selected the choice "Low" (31\%). Investigating the statistics relating to the item of "collection of waste" showed that most respondents (32.3\%) selected the choice "High". Investigating the item of "quality of cleaning and hygiene" showed that most respondents selected the choice "High" (34.3\%). Regarding the item of “access to water for farming” most respondents selected the choice "Low" (34.5\%). Elaborating on the statistics relating to the item of "number of natural outlooks", showed that most respondents have selected the choice “Average” (43.5\%). Nevertheless, investigating the statistics relating to the item of "amount of landscape" revealed that most respondents have selected the choice "Average” (33.9\%). Since the studied components are comprised of more than one item with low scales, therefore it is necessary to select a proper normality test for the research variables. The results are reported in the following table. 


\section{Table 4}

Testing the normality of research variables

\begin{tabular}{lrrrrrr} 
Variable & Average & \multicolumn{1}{c}{ S.D } & Skewedness & Elongation & \multicolumn{1}{c}{ Least } & \multicolumn{1}{c}{ Highest } \\
\hline Employment & 3.199 & 0.801 & -0.698 & 0.162 & 1.00 & 4.50 \\
Income & 2.635 & 0.570 & 0.006 & -0.237 & 1.00 & 4.00 \\
Investment & 2.596 & 0.601 & -0.236 & -0.035 & 1.00 & 4.00 \\
$\begin{array}{l}\text { Environment } \\
\text { Quality }\end{array}$ & 2.884 & 0.933 & -0.251 & -0.853 & 1.00 & 4.50 \\
$\begin{array}{l}\text { Outlook } \\
\text { Climate }\end{array}$ & 2.609 & 1.090 & 0.607 & -0.505 & 1.00 & 5.00 \\
$\begin{array}{l}\text { Economic } \\
\text { Dimension }\end{array}$ & 2.810 & 0.500 & -0.614 & 0.681 & 1.17 & 3.83 \\
$\begin{array}{l}\text { Environmental } \\
\text { Dimension } \\
\text { Life Quality }\end{array}$ & 2.746 & 0.936 & 0.171 & -0.554 & 1.00 & 4.75 \\
& 3.092 & 0.675 & -0.137 & -0.895 & 1.67 & 4.47
\end{tabular}

Absolute values of skewedness coefficient of smaller than 3 and absolute values of elongation of smaller than are considered as normal for the variables (Clean, 2010). As you can see in table 5, for the entire variables of the study the values of skewedness and elongation coefficients are located in the mentioned range, and their normality is accepted.

\section{Comparing the dimensions of the study with the median}

Since all 4 dimensions have normal distribution, we can use the one sample t-test to compare the average values of the components with the value of 3 (the median of the 5-degree Liker Scale). The results are reported in the following table: 
Table 5

Results of comparison of means of research dimensions with value 3 using t-test

\begin{tabular}{|c|c|c|c|c|c|c|c|}
\hline Component & Count & Average & S.D & T-stat & F.D & Value & Result \\
\hline Employment & 356 & 3.199 & 0.801 & 4.697 & 355 & 0.000 & $\begin{array}{l}\text { Above } \\
\text { AVG. }\end{array}$ \\
\hline Income & 356 & 2.635 & 0.570 & -12.078 & 355 & 0.000 & $\begin{array}{l}\text { Above } \\
\text { AVG. }\end{array}$ \\
\hline Investment & 356 & 2.596 & 0.601 & -12.698 & 355 & 0.000 & $\begin{array}{l}\text { Above } \\
\text { AVG. }\end{array}$ \\
\hline $\begin{array}{l}\text { Environment } \\
\text { quality }\end{array}$ & 356 & 2.884 & 0.933 & -2.343 & 355 & 0.020 & $\begin{array}{l}\text { Above } \\
\text { AVG. }\end{array}$ \\
\hline $\begin{array}{l}\text { Outlook and } \\
\text { climate }\end{array}$ & 356 & 2.609 & 1.090 & -6.774 & 355 & 0.000 & $\begin{array}{l}\text { Above } \\
\text { AVG. }\end{array}$ \\
\hline $\begin{array}{l}\text { Economic } \\
\text { dim. }\end{array}$ & 356 & 2.810 & 0.500 & -7.170 & 355 & 0.000 & $\begin{array}{l}\text { Above } \\
\text { AVG. }\end{array}$ \\
\hline $\begin{array}{l}\text { Environmental } \\
\text { dim. }\end{array}$ & 356 & 2.746 & 0.936 & -5.109 & 355 & 0.000 & $\begin{array}{l}\text { Above } \\
\text { AVG. }\end{array}$ \\
\hline Life quality & 356 & 3.092 & 0.675 & 2.583 & 355 & 0.010 & $\begin{array}{l}\text { Above } \\
\text { AVG. }\end{array}$ \\
\hline
\end{tabular}

In t-test, if the divided by two measure of value equals a number smaller than 0.05 , with respect to the state of the t statistic (positive or negative), it can be concluded what the status of the component of interest is. However, if the t-statistic is negative, the component under investigation has an average of smaller than 3 in the sample. If the divided by two measure of value equals a number smaller than 0.05 , and the t-statistic is positive, it is concluded that the component under investigation has an average of larger than 3 in the sample. On the other hand, if the divided by two measure of the value is larger than 0.05 , the average of the component under investigation has no statistically significant difference with the median of 3 in the sample. In the following table, the significance of the hidden paths between the hidden variables have been statistically investigated using t-test. 


\section{Table 6}

Results of research structural model

\begin{tabular}{llllll} 
Path & $\begin{array}{l}\text { Standardized } \\
\text { Path } \\
\text { Coefficient }\end{array}$ & S.D & t-statistic & value & Result \\
\hline $\begin{array}{l}\text { Economic } \\
\text { population } \\
\text { retention }\end{array}$ & 0.051 & 0.047 & 1.072 & 0.284 & Insignificant \\
$\begin{array}{l}\text { Economic } \\
\text { population } \\
\text { retention }\end{array}$ & 0.208 & 0.103 & 2.017 & 0.044 & significant \\
\end{tabular}

The general rule for deciding making with structural equations based on t-values implies that if the absolute value of $t$-value for a certain coefficient is higher than 1.96 , that coefficient will be considered significant at a confidence of $95 \%$.

\section{Discussion}

According to the results obtained from structural equations, the effect of economic dimension of life quality on retention of population has been investigated, and the results show that the economic dimension of life quality is not statistically of significant effects on retention of population in rural areas; in the other words, the first hypothesis of the study is rejected under a confidence of $95 \%$.

Taking a look at table 8 shows that the economic status of villages in Narimani Sofla (existence of employment opportunities, employment in services sector, being placed on the traffic routs, population growth), Kal Choqoki (Access to proper jobs in adjacent villages, employment in services section), Kalate Mirzajani (employment in agriculture), are in terms of employment, in a better situation compared to the rest of the villages. However, in terms of the component of income, the villages of Derakht Bid (properness of ranching because of being located on the slopes of mountains, harvesting crops in different manners) and Narimani Sofla (suitability of the volume and type of economic transactions with other areas, especially with the city of Mashhad; the most income being generated by agriculture) are in a suitable situation. Nevertheless, in terms of the 
component of investment, the village of Narimani Sofla (privacy of the ownership of majority of lands and residences) is of an almost suitable status, while other villages are unsuitably positioned.

\section{Table 7}

The status of economic dimension in villages under study

\begin{tabular}{llll} 
Village & Employment & income & Investment \\
\hline Abravan & 2.924 & 2.651 & 2.372 \\
Chenarak & 2.952 & 2.121 & 2.306 \\
Derakht Bid & 3.000 & 3.300 & 2.800 \\
Dom rooba & 2.231 & 2.500 & 2.231 \\
Shurak Maleki & 2.884 & 2.407 & 2.988 \\
Qarne Sofla & 3.000 & 2.773 & 2.000 \\
Kal Choqoki & 3.776 & 2.691 & 2.539 \\
Kalate Menar & 2.545 & 2.273 & 2.227 \\
Kalate Mirzajani & 3.692 & 2.962 & 2.500 \\
Giami & 2.536 & 2.321 & 2.179 \\
Mirinkesh & 2.813 & 2.156 & 2.625 \\
Narimani Sofla & 3.848 & 3.065 & 2.087 \\
& & & \\
\hline Total & 3.199 & 2.635 & 2.596
\end{tabular}

According to the comparative statistics reported by table 7, it can be seen that the median of the component under study is not similar for the villages of the study; according to these results, the medians are not equal and so there exists significant differences, while the highest AVG. value among the three components of the economic dimension is associated to the village of Narimani Sofla.

The findings of this part of the study show that the effects of the economic dimension are not positive on the quality of life, and this result is consistent with the result obtained by Rezvani and Mansourian (2015); Poortaheri, Eftekhari \& Fatahi (2012); Barani-Pesian (2015); Azizpoor \& Afrakhte (2015), Badri et al., (2014); however the results are inconsistent with the results obtained by Qanbari et al., (2014); Anabestani \& Roosta (2016); and Shariatpanahi (2019).

Other results of the study have shown that the environmental dimension of life quality is of statistically significant effects on retention of population in rural areas; in the other words, the second hypothesis of the study is accepted under a confidence of 95\%. 
Investigating table 5 shows that the villages of Kalate Mirzajani, Narimani Sofla, Abravan, Shurak Maleki (quality of sidewalks, hygiene and cleaning, collection of waste) are in terms of the component of quality of environment in a better situation compared to other villages. In addition, regarding the component of outlook and climate, the villages of Narimani Sofla, kal Choqoki (access to enough farming water, existence of natural outlooks, landscape) are in a suitable situation.

Findings of this section of the study show that the effects of the environmental dimension have statistically significant and positive effects on quality of life. These results are consistent with the results obtained by Mahdavi (2015); Badri (2014); Poortaheri \& Eftekhari (2012); Rezvani \& Mansourian (2012); Beshaq et al., (2015); Riahi (2014), and Sheikhi (2018).

\section{Conclusion}

Considering the findings, solutions such as development of industrial activities for creating more employment opportunities; improving the infrastructures of ranching; development and expansion of infrastructures of on-the-road services with respect to requiring low capital but giving high income and considering the fact that the village is located on the transit-route between Sarakhs-Turkmenistan, development of maintenance services such as repair centers.

Considering the fact that certain transit routes pass through these villages, widespread of greenhouse farming with respect to water deficiency in the villages, developing ranching complexes outside the villages, changing farmers' farming patterns and condensing the agriculture, stopping construction in the vicinity of railways, development and amplification of the vegetation to control the floods, equipping farms with novice irrigation systems, asphalting the main roads, developing the landscapes, developing the sidewalks with pavements, constructing walking bridges and underpasses in the old Mashhad-Sarakhs way for villages that are challenged by such lacks.

\section{References}

Alavizadeh, A. M. (2013). The role of non-agricultural economy on rural sustainability in rural areas of Semirom city. Regional Planning Quarterly, 3(10), 12-30. http://jzpm.miau.ac.ir/article_32.html 
Anabestani, A. A. (2012). Spatial analysis of factors affecting the quality of life in rural settlements (sample: Simkan section of Jahrom city). Regional Planning Quarterly, 15(18), 126-138. https://profdoc.um.ac.ir/paper-abstract-1048283.html

Andrews, F. M., Withey, S. B. (1976). Social indicators of well-being: Americans' perceptions of life quality. New York: Plenum Press. https:/www.springer.com/gp/book/9781468422559

Azizpour, F., Hassan, A. (2014). Spatial Analysis of Quality of Life in Rural Settlements (Case: Gorgan County Explosive Village). Quarterly Journal of Space Economics and Rural Development, 3(1), 7-15. https://serd.khu.ac.ir/article-1-1955-fa.html

Barani Pesyan, V. (2014). Assessment and analysis of quality of life of rural households with emphasis on demographic variables Case study: Rural households in Aj Bashir. Rural Research, 5(1), 45-66. 10.22059/jrur.2014.51448

Barimani, F., Baluchi, O. (2013). Evaluation of quality of life in rural areas using intelligent systems (fuzzy logic) (Case study: Mehban sub-district of Nikshahr city). Rural Research, 4(3), 78-98. 10.22059/jrur.2013.36495

Beesley, K. B., Russwurm, L. H. (1989). Social indicators and quality of life research: Toward $\begin{array}{lll}\text { synthesis. } & \text { Environments, }\end{array}$ https://link.springer.com/article/10.1007/BF00353138

Calman, K. C. (1994). Quality of life in Cancer Patients- A Hypothesis. Journal of Medical Ethics. 10, 89-95. doi: $\underline{10.1136 / j m e \cdot 10.3 .124}$

Clarke, P. J., Marshall, V. W., Ryff, C. D., Rosenthal, C. J. (2000). Well being in Canadians eniors:Findings from the Canadian Studyof Healthand Aging. Canadian Journal on Aging,19, 87-121. DOI: https://doi.org/10.1017/S0714980800013982

Cramer, V., Seven, T. Einar, K. (2004). Quality of Life in a City: The Effect of Population Density". Social Indicators Research. https://link.springer.com/article/10.1023/B:SOCI.0000032663.59079.0b

Das, D. (2008). Urban Quality of Life: A Case Study of Guwahati. Social Indicators Research, 88. https://link.springer.com/article/10.1007/s11205-007-9191-6

De Leo, D., Diekstra, R. F., Lonnqvist, J., Trabucchi, M., Cleiren, M. H., Frisoni, G. BSampaio Faria, J. (1998). LEIPA D: An internationally applicable instrument to assess quality of 
life in the elderly Behavioral Medicine.Washington, D.C publisher. https://apps.who.int/iris/handle/10665/108515

Foo, T. S. (2017). Subjective Assessment of Urban Quality of Life in Singapore (1997-1998). Habitat International, 24(1), 33-51. https://www.semanticscholar.org/paper

Ghanbari, Y. (2013). Measurement and evaluation of quality of life index in rural areas (Case study: Miandeh village, Fasa city). Journal of Rural Research and Planning, 3, 90-111. https://doi.org/10.22067/jrrp.v2i3.17743

Horváth, A., \& Jónás-Berki, M. (2018). Environmental and social responsibility supplemented with green case studies from the side of the tourism service providers. Turizam, 22(2), 5262. DOI: $10.5937 / 22-17527$

Hosseini, H., Bagherian, K. (2014). An Analysis of the Constituent Components of Quality of Life in Nowshahr. Quarterly Journal of Environmental Planning, 27, 89-98. http://jest.srbiau.ac.ir/article_6433.html

Mathew, P. V., \& Sreejesh, S. (2017). Impact of responsible tourism on destination sustainability and quality of life of community in tourism destinations. Journal of Hospitality and Tourism Management, 31, 83-89. https://doi.org/10.1016/j.jhtm.2016.10.001

Mir Latifi, M., Seyed Amir Mohammad, A. (2013). The role of non-agricultural economy on the sustainability of villagers in rural areas of Semirom city. Quarterly Journal of Regional Planning, 3(10), 90-99. http://jzpm.miau.ac.ir/article_32.html

Mohammadi, Y., Behrooz, M. (2013). The Role of Housing Improvement Credits on Improving the Quality of Life in Rural Areas Case Study: Zanjan County, Miracles. Housing and Rural Environment, 14(1), 11-35. http://psp.journals.pnu.ac.ir/m/article_4396_0.html

Nillson, J. (2006). "Social Capital and Quality of life in the old Age". Journal of Aging and Health, 18(3), 65-76. http://jgn.medilam.ac.ir/article-1-135-fa.pdf

Nourbakhsh, S., Mohammad Akbarpour, S. (2011). Strategies to combat rural-urban migration using Swat technique (Case study of Kuhsar village of Hashtrood city). Rural Development, 3(2), 34-65. https://www.magiran.com/paper/998997

Pacione, M. (2003). Urban Environmental Quality and Human Wellbeing; A Social Geographical Perspective. Landscape and Urban Planning, 6(5), 52-65. https://www.sciencedirect.com/journal/landscape-and-urban-planning/vol/65/issue/1 
Pal, A. K., Kumar, U. C. (2005). Quality of life concept for the Evaluation of Societal development of rural community in west Bangal, India. Journal Rural Development, 15, 267-278. https://doi.org/10.1177/1018529120050205

Poor Taheri, M., Eftekhari, A, S. (2011). Quality of Life Assessment in Rural Areas Case Study: North Khava County, Lorestan Province. Human Geography Research, 76, 358-377. https://www.sid.ir/fa/journal/ViewPaper.aspx?id=132236

Rezvani, M., Seyed Ali, B., Farkhondeh Sepahvand, S., A. (2019). Second house tourism and its effects on improving the quality of life of rural residents (Case study: Rudbar Qasran, Shemiranat. urban and regional studies and researches, 3(4), 87-110. http://urs.ui.ac.ir/article_20014.html

Rostamalizadeh, V. (2013). Factors Affecting the Sustainability of Rural Youth Case Study: Ahar County. Rural Research, 4(3), 156-167. 10.22059/jrur.2013.36492

Ruževičius, J. (2012). Quality management. Global concept and research in the field, Vilnius: Akademinė leidyba publishing house. http://dx.doi.org/10.5200/ibl.2012.07

Su, L., \& Swanson, S. R. (2017). The effect of destination social responsibility on tourist environmentally responsible behavior: Compared analysis of first-time and repeat tourists. Tourism Management, 60, 308-321. https://doi.org/10.1016/j.tourman.2016.12.011

Zhang, Y., Zhang, J., Ye, Y., Wu, Q., Jin, L., \& Zhang, H. (2016). Residents’ environmental conservation behaviors at tourist sites: Broadening the norm activation framework by $\begin{array}{llll}\text { adopting environment } & \text { attachment. Sustainability, }\end{array}$ https://doi.org/10.3390/su8060571 